\title{
A város- és várostérség-tipizálás alapjai Kelet-Közép-Európában
}

\section{The bases of a typology of cities and urban areas in Central and Eastern Europe}

\author{
EGRI ZOLTÁN
}

EGRI Zoltán: egyetemi adjunktus, Szent István Egyetem, Gazdasági, Agrár- és Egészségtudományi Kar, Szarvas; egri.zoltan@gk.szie.hu

KULCSSZAVAK: város, városi térség, tipizálás, módszertan, területi fejlődés, Kelet-Közép-Európa

ABSZTRAKT: A tanulmány célja a napjainkban is átalakuló kelet-közép-európai térség területi egyenlőtlenségeinek, sajátosságainak bemutatása, a városok, városi térségek tipizálásával. Napjainkban a városkutatások reneszánszát tapasztalhatjuk, a városok a regionális és az országos gazdasági növekedés, a fejlődés és a versenyképesség gócpontjai, amelyekben igen koncentráltan zajlanak a térbeli folyamatok. A cikk kísérletet tesz a napjainkban jelentős város- és várostérség-vizsgálatok bemutatására, azok különböző értelmezéseinek és módszertani sajátosságainak ismertetésére. Ezen túl a tanulmány a városi teljesítmény indikátorait is azonosítja és Kelet-Közép-Európa városhálózatát, várostérképét is „megrajzolja”.

Összességében kijelentheto", hogy a város nem minden esetben város, annak szükebb-tágabb vonzáskörzete, hinterlandja szinte minden esetben megjelenik a különböző társadalmi-gazdasági tartalmú területi elemzésekben. A főbb európai dokumentumokat áttanulmányozva megállapítható, hogy elég sok és sokszínű város- és várostérség-tipizálással találkozhatunk; ezek módszertanai, lehatárolásai diverznek mondhatók. Az irodalmi feldolgozás során összegeztem a városi teljesítmény tényezőit, a gazdasági teljesítmény, a gazdasági szerkezet, az elérhetőség, a demográfia, az innovációs teljesítmény és az infokommunikáció, valamint a területhasználat mutatóit. Ahogy a város- és várostérség-kategorizálás is sokszínű, úgy a kelet-közép-európai városhálózat is differenciált képet nyújt, annak függvényében, hogy milyen területi szinten vizsgálódunk.

Zoltán EGRI: assistant professor, Faculty of Economics, Agriculture and Health Studies, Szent István University, Szarvas; egri.zoltan@gk.szie.hu

KEYWORDS: city, urban area, typology, methodology, regional development, Central and Eastern Europe

ABSTRACT: The aim of this study is to show the regional inequalities and special features of Central and Eastern Europe which is considered a region still in transition. In other words, the

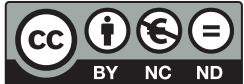


purpose is to classify cities and urban regions. Today, we can see a revival of urban research. As focal points of regional and national economic growth, development and competitiveness, cities are the venues of spatial processes taking place in a fairly concentrated form.

This study seeks to describe today's major efforts in the field of city and urban region analyses as well as to highlight the various interpretations and methodologies of the same. Furthermore, the study identifies urban performance indicators and "draws" a map of the urban network of Central and Eastern Europe. Based on numerous literature sources, the study deals with several spatial levels from the "actual" urban level to the research projects completed at a regional level.

The study starts by presenting spatial and methodological information on the flagships (the so-called MEGA areas) of polycentric regional development, and arrives at an important conclusion about the primary role played by Berlin and Vienna in the region. Actually, the "new" capitals represent the secondary line, while the weak MEGAs at the bottom of the urban hierarchy act as development hubs in the region. Even the contours of a new integration zone become visible in the region. This zone is forming along Pan-European corridor VI with the involvement of Vienna, Prague, Bratislava, Budapest (and Zagreb).

Another major data source for urban-level measurements is the urban audit, coordinated by Eurostat, which has already supplied databases for a multitude of studies. This source represents a substantial innovation in urban research efforts as it includes multi-layer data, contains long statistical data series and allows comparisons in both time and space. Nevertheless, it also has many disadvantages including, in particular, lack of data and national features in the delimitation of urban agglomerations. In my opinion, this fact makes a lot of analytical surveys unreliable. One of the most widespread analyses of the rural/urban issue is the version adapted to NUTS 3 and based on population density. Developed formerly by the OECD, this model has undergone many changes. As a result, its recent versions place greater emphasis on the role of cities. The research results of Bengs and Schmidt-Thomé (ESPON 1.1.2) have contributed to the clarification of urban-rural relations at the level of NUTS 3. This survey draws the demarcation lines of urban regions in view of population density as well as other factors (central town status of the region, land use indicators). In my effort to further differentiate the notion of the city as a territorial unit, I have found several publications using the expression of metropolitan regions or metro regions. The special region is defined as the cities and urban agglomerations shown in the urban audit, which are manifested at NUTS 3 level(s). Unique efforts are seen in the ESPON FOCI project, where the units of observation are the city areas and their regional hinterland.

Accordingly, a city is "not always a city" because its smaller or bigger agglomeration or hinterland is almost always present in the various social or economic surveys of the given region. Based on a review of the main European documents, I may state that the efforts launched to classify cities and urban agglomerations are fairly wide-ranging. What is more, the associated interpretations and methodologies are also diverse. According to my literature review, the primary and supplementary factors of urban performance are the following: economic output, economic structure, accessibility, demography, innovative performance, infocommunications and land use indicators. Similarly to the varied picture found regarding the categorisation of cities and urban agglomerations, the Central and Eastern European urban network is also very differentiated depending on the spatial level of the actual analysis. 
Látni kell, hogy a fejlődés gyújtópontjai a városok, „mivel ebben a területi egységben koncentráltan zajlanak a térbeli folyamatok, azok jellege, funkcióik sajátosságai részben meghatározzák térségeik fejlődését, részben pedig hordozzák és kifejezik a versenyképességet." (Rechnitzer 2006)

„A városok társadalmunk vibráló impulzusai." (Hahn, EC 2010a)

\section{Bevezetés, célkitüzések}

Az új évezred elejétől a városkutatások reneszánszát tapasztalhatjuk. Az 1999-ben megjelent Európai területfejlesztési perspektíva (ESDP) új térségi szerepkört szán a városoknak. A dokumentum 67-78. pontjai többek között leszögezik, hogy „policentrikus fejlesztési koncepciót kell alkalmazni ahhoz, hogy regionálisan kiegyensúlyozott fejlődést lehessen elérni, (...) az EU összes régiója gazdasági potenciálját csak akkor lehet kihasználni, ha továbbfejlesztjük a policentrikus településhálózatot.” (EC 1999) A dokumentum megjegyzi azt is, hogy „az olyan területfejlesztési perspektíva, amely egyes világvárosi térségek policentrikus fejlesztésére korlátozódik, nincs összhangban az EU azon hagyományával, amely a város és a vidék sokszínűségének fenntartását tartja szem előtt. Ezért célként az EU egész területét felölelő policentrikus településhálózatot kell kitűzni." ${ }^{1}$ A tanulmány szerint a többközpontú hálózat kiépítése azért is fontos, mert Európa területi egyensúlyának javításában a megfelelő világgazdasági integrációval rendelkező dinamikus övezetek kulcsszerepet játszanak. Ezek nemzetközileg elérhető világvárosi régiók hálózatából és háttérterületeikből állnak, így a vidéki területek fejlesztése is megtörténik. A cikkben alapvetően nem a policentrikus térszerkezet vizsgálata a célom, inkább csak alapfelvetésként alkalmazom a fenti sorokat, hangsúlyozva a városok fejlődésben betöltött szerepét.

A ma fennálló, nem éppen kedvező helyzetet számos dokumentum elemezte. A városok az európai gazdaság motorjai, a kreativitás és az innováció katalizátorának szerepét tölthetik be az EU-ban. Az ötödik kohéziós jelentés (EC 2010b) szerint az EU-ban a nagyvárosi régiók adják a lakosság 60\%-át és a bruttó regionális termék 68\%-át. Egy másik statisztikai adatsor szerint a Pentagon térségben (a London-Párizs-Milánó-München-Hamburg városokkal határolt régióban), amely az EU legurbanizáltabb térsége, az unió népességének közel egyharmada, a megtermelt GDP közel fele és a kutatás-fejlesztési kiadások háromnegyede összpontosul. Ugyanakkor a jólét, a magas hozzáadott értéket előállító ágazatok, munkahelyek magas aránya mellett számos problémával is kénytelenek szembesülni ezen agglomerációk: ilyen például a szegénység és a társadalmi kirekesztés kockázata, ${ }^{2}$ valamint a környezeti fenntarthatóság kérdése. 
Tanulmányomban a napjainkban is átalakuló kelet-közép-európai térségre koncentrálok, elsődleges célom bemutatni az itt lévő városok, várostérségek „mérését”, tipizálását, kategorizálását. Az alábbi kérdésekre keresem a választ:

- Hogyan határozza meg napjainkban a várost vagy városi térséget a szakirodalom?

- Milyen területi szinten érdemes és szükséges vizsgálódni?

- Hogyan mérjük a várost, a városias térségeket? Milyen módszerek segítik a tipizálást?

- Melyek a városi teljesítmény indikátorai?

- Hogyan néz ki Kelet-Közép-Európa városhálózata, „várostérképe”?

A dolgozat vizsgálati terét, Kelet-Közép-Európát az alábbi országok jelentik: a balti országok, a visegrádi térség, Kelet-Németország, Szlovénia, Románia, Bulgária. A szakirodalmi feldolgozás során ezen országok városait, városi térségeit emelem ki (ahol lehetséges), európai és kelet-közép-európai kontextusban mutatom be szerepüket.

A feldolgozás alapja az ESPON és az Eurostat kiadványai és projektjelentései. Az eredményeket a városi szinttől kiindulva a magasabb térségi szintek (alrégió, régió, nagytérség) felé haladva tekintem át.

\section{A városi szintű elemzések főbb eredményei}

A policentrikusság ${ }^{3}$ célkitűzése hosszú évtizedek óta visszatér az európai területi gondolkodásban. Az európai területpolitika 1999-ben erősítette meg az Európai Unióra a többközpontú településhálózat megteremtésének célkitűzését, mely azóta is az európai területi prioritások egyik legfontosabb eleme. Az Európai Unió Területi agendája hasonlóképp fontosnak ítélte meg, hogy a fejlődés vázát a többközpontú településhálózat adja. A policentrikusság európai célkitüzésének egyik fontos eleme, hogy a fejlődés ne a Pentagon területére koncentrálódjon, hanem e területen kívül is legyenek olyan erős városias térségek, amelyek az Európai Unió területileg kiegyensúlyozott fejlődését segíthetik elő (NFGM, VÁTI 2010).

Az ESPON kutatási hálózat számos tanulmányt jelentetett meg az ESDP-ben célként megjelölt többközpontú területi fejlődésről. Az első jelentős kutatási eredményeket a Nordregio által koordinált projekt adta (ESPON 2005), amely az európai térség policentrikus fejlődését mutatja be A 27+2 (EU, Norvégia és Svájc) országból álló területen 1595 funkcionális városi területet azonosítottak. A városi területek tipizálása ${ }^{4}$ az európai kontextusban mért funkcionális jelentőség alapján történt, ezt az 1. táblázat bal oldali oszlopa ismerteti. A többféle területi adatbázison, az egyes funkciók rangsorolásán alapuló módszertannal háromszintű városkategorizálást hoztak létre. A legtöbb pontot elérő 76 város az európai növekedési nagyvárosi terület (MEGA), 219 város a transznacionális 
vagy nemzeti városi terület, a maradék 1312 pedig a regionális vagy helyi városi terület besorolást kapta. A MEGA-kat négy kritérium alapján továbbosztották (hiszen ezek a Pentagon térség lehetséges ellenpólusai). A tömeg funkcióját a népesség mellett a GDP is képviseli, a versenyképességet az egy főre jutó GDP és az 500 legnagyobb vállalat megléte. Az elérhetőségi dimenzióban megjelenik a légi forgalom és a multimodális megközelíthetőség. A negyedik kritérium a tudás, azaz a képzettségi szint és a kutatás-fejlesztésben foglalkoztatottak aránya. ${ }^{5} \mathrm{Ez}$ alapján a MEGA-területeket öt kategóriába sorolták: globális csomópontok, Európa motorjai, erős, potenciális és gyenge MEGA-központok. A kelet-közép-európai térségben két fejlődési góc található, az Európa motorjai kategóriába tartozó Bécs és Berlin uralja a teret. Az új tagállamokban a fővárosok jelennek meg növekedési központként (a potenciális MEGA-tábort erősíti Varsó, Prága, Pozsony és Budapest). Egyéb, a fejlett városhierarchia alján lévő városok (gyenge MEGA-k) is fejlődési csomópontok lehetnek (Katowice, Krakkó, Gdańsk-Gdynia-Sopot, Łódź és további lengyel nagyvárosok, valamint Ljubljana, Bukarest, Temesvár és Szófia). Illés (2005) szerint új csomópontként a Bécs-Prága-Pozsony-Budapest térség ellensúlyozhatja (részben - saját megjegyzés) a Pentagon térséget. Itt jelenhet meg egy új integrációs zóna, amely Zágráb felé folytatódhat. A transznacionális régió kialakulását nagyban elősegíti a városokat, azok térségeit összekötő infrastrukturális hálózat, a VI. páneurópai korridor.

Az IGEAT által vezetett újabb ESPON-projekt (2007) felülvizsgálta a korábbi kutatásokat. Újból definiálták a fóbb városi funkciókat, azok tartalmait kiegészítették. Az 1. táblázat jobb oldali oszlopában látható mutatórendszer szofisztikáltabb, így a kimutatott városszerkezet is összetettebb. Habár az adatbázis kifinomultabb volt, a globalizációs indikátorokat is szükséges lett volna kiegészíteni, például az infokommunikációs technológiák szektorával, az ipar helyett a tercier szektor bruttó hozzáadott értékével (bár ez közvetve megjelenik a nemzetközi döntéshozatal mutatójában), valamint egyéb, gazdasági sűrüséget kifejező indikátorokkal.

A kutatás négy kategóriát határozott meg a népességszám alapján: metropoliszok, nagy, közepes és kis funkcionális városi térségek. A metropoliszokat differenciálták: a két vagy több város alkotta metropolisz a policentrikus metropolisz elnevezést kapta. Az újabb lehatárolás alapján összetettebb képet kapunk a térség városi szerkezetéről, főleg az eddig (inkább) monocentrikusnak nevezett országok esetében. Csehországban Prága mellett ellenpólus Ostrava és Brno (többközpontú metropoliszok), illetve nagy funkcionális városi térség Plzeň. Magyarországon közepes méretü funkcionális városi térség Miskolc és Debrecen. Romániában jóval több nagyobb város tűnik fel a térképen: Bukarest metropolisz mellett Temesvár, Konstanca, Kolozsvár, Jászvásár, Brassó, Galac és Craiova. A kutatás fontos eredménye a határon átnyúló funkcionális városi területek azonosítása. Metropolisz- és többközpontú határon átnyúló funkcionális városi térség Kelet-Közép-Európában a sziléziai-morva térség (5,3 millió fö) és Bécs-Pozsony-Mosonmagyaróvár (3,4 millió fö). Határon átnyúló nagyváros 
1. táblázat: A policentrikus városképet ismertető főbb ESPON-kiadványok funkció- és mutatókészlete

Set of functions and indicators in ESPON publications about polycentricity

\begin{tabular}{|c|c|c|}
\hline Dimenziók & ESPON 1.1.1. & ESPON 1.4.3. \\
\hline Tömeg & $\begin{array}{l}\text { A funkcionális várostérség } \\
\text { népessége }\end{array}$ & A magváros és a vonzáskörzet népessége \\
\hline Közlekedés & $\begin{array}{l}\text { Légi közlekedés és kikötői } \\
\text { forgalom (bizonyos határ } \\
\text { felett) }\end{array}$ & Közúti, vasúti és légi kapcsolódás, kikötői forgalom \\
\hline Turizmus & $\begin{array}{l}\text { Kereskedelemi } \\
\text { szálláshelyek } \\
\text { férőhelyeinek száma }\end{array}$ & $\begin{array}{l}\text { Kereskedelemi szálláshelyek férőhelyeinek száma, } \\
\text { eltöltött vendégéjszakák száma, turisztikai minősítés } \\
\text { mutatói }\end{array}$ \\
\hline Ipar & $\begin{array}{l}\text { Az ipar bruttó hozzáadott } \\
\text { értéke (euró) }\end{array}$ & Az ipar bruttó hozzáadott értéke (euró) \\
\hline Tudás & $\begin{array}{l}\text { Egyetemek megléte, } \\
\text { felsőfokú képzésben } \\
\text { résztvevők száma }\end{array}$ & $\begin{array}{l}\text { Az } 500 \text { legjobb európai egyetem és a } 100 \text { legjobb } \\
\text { kutatóintézet megléte, a high-tech és tudásintenzív } \\
\text { szolgáltatásokban és iparágakban foglalkoztatottak } \\
\text { aránya }\end{array}$ \\
\hline Közigazgatás & $\begin{array}{l}\text { Az adott város szerepe a } \\
\text { decentralizáció } \\
\text { függvényében }\end{array}$ & $\begin{array}{l}\text { Nemzeti szinten: a decentralizáció függvénye } \\
\text { Nemzetközi szinten: nemzetközi szervezetek jelenléte } \\
\text { (EU, EKB, NATO, UNESCO, ENSZ stb.) }\end{array}$ \\
\hline Döntéshozatal & $\begin{array}{l}\text { Az } 500 \text { európai } \\
\text { nagyvállalat központjainak } \\
\text { megléte }\end{array}$ & $\begin{array}{l}\text { Nemzeti szinten: a föbb vállalati központok és a } 200 \\
\text { legnagyobb hazai vállalat alközpontjainak megléte } \\
\text { Nemzetközi szinten: a } 2000 \text { legnagyobb nemzetközi } \\
\text { vállalati központjának megléte, a nemzetközi } \\
\text { szolgáltatásokhoz való hozzáférés }\end{array}$ \\
\hline
\end{tabular}

Forrás: ESPON 2005, ESPON 2007 alapján.

Salzburg és Rusze-Gyurgyevó ikervárosok. Közepes méretű határon átnyúló térségeket a német-lengyel, az olasz-szlovén, valamint az osztrák-német határ mentén találunk, kisméretű határon átnyúló városi tereket pedig a magyar-szlovák határ mentén (Komárom-Révkomárom, Esztergom-Párkány).

A városi szintű mérés másik fontos adatforrása az Eurostat által koordinált urban audit. Az Európai Unió döntéshozói felismerték a városok jelentőségét az egységes Európában. Sem a területi különbségek mérséklése, sem pedig bizonyos gazdasági, társadalmi problémák kezelése nem lehetséges a városok helyzetének ismerete nélkül (Kezán 2006). Az urban audit öt szinten gyüjt adatokat: a magváros (a közigazgatási határokkal körülvett város), az agglomeráció (larger urban zone, LUZ, ingázási körzet), a városrész (településrész, kerület), a kernel (az „alulhatárolt” fóvárosok esetében ${ }^{6}$ ) és az ország szintjén. Módszertani szempontból az agglomerációk lehatárolása érdekes, egyben megnehezíti az egységes értelmezést. A kelet-közép-európai térségben, például Ausztriában a NUTS 3 szint jelenti a LUZ-t (Bécs esetében már több NUTS 3 térség alkotja a 
vonzáskörzetet), Bulgáriában a LAU 1 szintü, ingázáson alapuló aggregáció a LUZ-lehatárolás alapja. (Kivétel a főváros, itt a NUTS 3 szint a vonzáskörzet.) Budapest esetében 79 település alkotja a LUZ-t. A lengyel városokban a város népessége határozza meg, hogy LAU 1 vagy LAU 2 a vonzáskörzet alapja, Romániában pedig távolsági kritériumot alkalmaznak (15 vagy $20 \mathrm{~km}$, annak függvényében, hogy a fővárosról vagy egyéb városról van szó). Ezért az urban audit városkörnyéki adatait fenntartással szükséges kezelni.

Az adatbázis számos területre kiterjed, például a demográfia, a társadalmi és a gazdasági helyzet mutatói, az állampolgári részvétel, a képzés és az oktatás, a környezet, a közlekedés és a szállítás, az információs társadalom, valamint a kultúra és rekreáció indikátorai érhetők el. Az adatgyűjtés nehézségeit jelenti többek között, hogy egyes adatok csak népszámlálásokból állnak rendelkezésre, a módszertanban a nemzeti sajátosságok miatt a megfelelő területi szintre nem állnak rendelkezésre adatok (Kezán 2006). A legtöbb esetben az urban audit a városok első három szintjén kínál statisztikai adatokat. Számos város esetében viszont nem ez a helyzet: van, ahol nincs agglomerációs adat, másoknál mind a városmag, mind az agglomeráció esetében ugyanazon adatok érhetők el, néhol két városmag ugyanazon agglomerációba tartozik (Bretagnolle, Delisle, Mathian, Lizzi, Guérois, Averlant 2011). A 2010-es State of European cities címü dokumentum a következő számokat közli: 356 magváros adatai ugyan elérhetőek, de LUZ-szinten csak 294-re áll rendelkezésre adat (RWI, Difu, NEA, PRAC 2010). A településrészi, kerületi szintű adatok szintén hiányosak. Sőt, az időbeli összehasonlítás is nehéz az adathiány miatt. Új kísérleti fejlesztésként jelent meg a Large City Audit (LCA), amely a 100000 fö feletti városokat foglalja magába.

Az első, 2007-es State of European cities című tanulmány tipizálja az európai térség városait az urban audit adatbázisa alapján. Az egyes városok besorolását méretük, gazdasági struktúrájuk, gazdasági teljesítményük és versenyképességük befolyásolja.7 A vizsgálati módszertan egyszerű, első lépésben a népesség és a gazdasági teljesítmény alapján differenciálják a városokat, majd ezen belül kategóriákat határoznak meg a többi mutató (innovációs teljesítmény, tehetség, kapcsolódás, vállalkozókészség) segítségével. (A kategóriákat az 1. ábra, a példákat a 2. táblázat mutatja be.)

Az ezredforduló adatain elvégzett elemzés sokszínűen mutatja be Európa, azon belül pedig Kelet-Közép-Európa városait. Ha nem is nyújt több információt a fejlődési gócpontokról, mint a korábbi MEGA-vizsgálatok, jóval differenciáltabb kép jelenik meg a vizsgált térségről. A jelentés alapján egyetlen tudásközpont sem lelhető fel Kelet-Közép-Európában. A térség híján van olyan, a nemzeti városhierarchián túllépő városnak, amely a nemzetközi ipar, szolgáltatások, tudás, pénzügyi szolgáltatások és elérhetőség frontvonalában lenne.

A második State of European cities kiadvány (RWI, Difu, NEA, PRAC 2010) a 2003-2004-es urban audit alapján tipizálja az európai városokat. A városi fejlődés, növekedés főbb dimenzióit az alábbiakban azonosította a jelentés: népesség, gazdaság, tudás, társadalmi kohézió, kormányzás, környezet és közlekedés. 
1. ábra: A városok kategorizálása a State of European cities (2007) alapján Categorization of cities according to the State of European cities (2007)

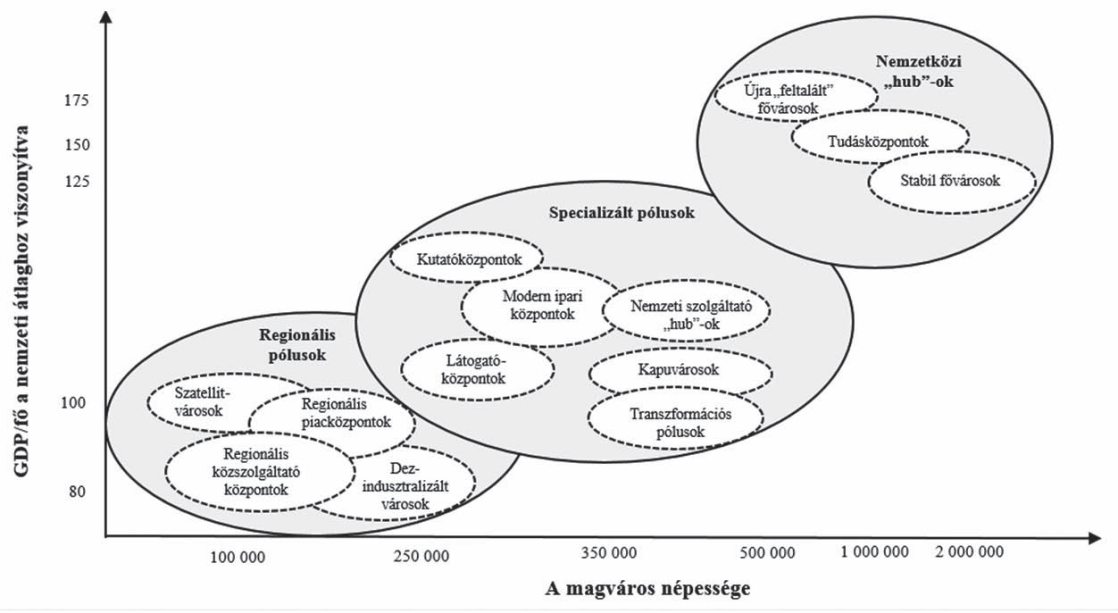

Forrás: EC 2007 alapján.

A főbb dimenziókhoz 21 mutatót rendeltek, ezek után faktorelemzéssel négy faktort határoztak meg. Azon mutatók, amelyek a legnagyobb mértékben korreláltak az egyes faktorokkal (népsürüség, 0-4 évesek korcsoportja, GDP/fö, felsőfokú végzettséggel rendelkező munkaképes lakónépesség), adták a klaszterelemzés alapját. A kétféle klaszterelemzést (hierarchikus és k-közép) diszkriminanciaanalízissel korrigálták. A módszertani fejezet szerint 356 város esetében az alábbi

\section{2. táblázat: Példák a városkategóriákra}

Examples of city categories

\begin{tabular}{|c|c|}
\hline Nemzeti „hub”-ok & $\begin{array}{l}\text { Stabil fövárosok: Bécs, Berlin } \\
\text { Tudásközpontok: - } \\
\text { Újra „feltalált” fóvárosok: az „új” fóvárosok }\end{array}$ \\
\hline Specializált pólusok & $\begin{array}{l}\text { Nemzeti szolgáltató „hub”-ok: Łódź, Brno, Plovdiv, Temesvár } \\
\text { Transzformációs pólusok: Drezda, Lipcse, Maribor, Plzeň } \\
\text { Kapuvárosok: Burgasz, Gdańsk, Rusze, Gyurgyevó } \\
\text { Modern ipari központ: Bydgoszcz, Graz, Linz, Arad } \\
\text { Kutatóközpontok: - } \\
\text { Látogatóközpontok: Krakkó, Várna, Weimar }\end{array}$ \\
\hline Regionális pólusok & $\begin{array}{l}\text { Dezindusztrializált városok: Kassa, Miskolc, Halle an der Saale, Katowice, Żory } \\
\text { Regionális piacközpontok: Pécs, Nyíregyháza, Erfurt, Nyitra } \\
\text { Regionális közszolgáltató központok: Magdeburg, Schwerin, Lublin } \\
\text { Szatellitvárosok: - }\end{array}$ \\
\hline
\end{tabular}

Forrás: EC 2007 alapján. 
esetek becsültek (regresszióelemzéssel): népsűrüség (89 város), 0-4 évesek korcsoportja (60 város), felsőfokú végzettséggel rendelkező munkaképes lakónépesség (215 város). A becslés nagy aránya miatt ez az elemzés (is) problémás.

A kelet-közép-európai térség homogén (2. ábra), a nagyobb városok, metropoliszok a fó nagyvárosok kategóriájában találhatók, pár regionális központ is fellelhető (föleg Kelet-Németországban), egyetlen kisebb központ (Kecskemét) van, a többség pedig a leszakadó régiók városait gyarapítja. A térképen nem jelennek meg az alkategóriák, ezeket a 3. táblázat közli példákkal.

A részletes csoportosítás sem ad sokkal kedvezőbb képet: a 94 városból 67 leszakadónak számít, ezen belül a rosszabbik csoportban román, lengyel és bolgár városokat találunk. A két középső kategóriában a „germán” városokon túl csak Plzeň és Kecskemét bukkan fel. Felsőbb szinten a fövárosokon kívül Gdańsk, Krakkó, Łódź, Poznań és Wrocław a jelentős hatással bíró európai gócpont.

Fontos megjegyezni, hogy a többváltozós elemzések szerint Berlin helyzete meggyengült, nem számít európai vezetőnek, „csupán” nemzeti pólus a fővárosok és a lengyel nagyvárosok mellett.

\section{2. ábra: Várostipológia a 2004-es urban audit alapján}

City typology according to urban audit (2004)

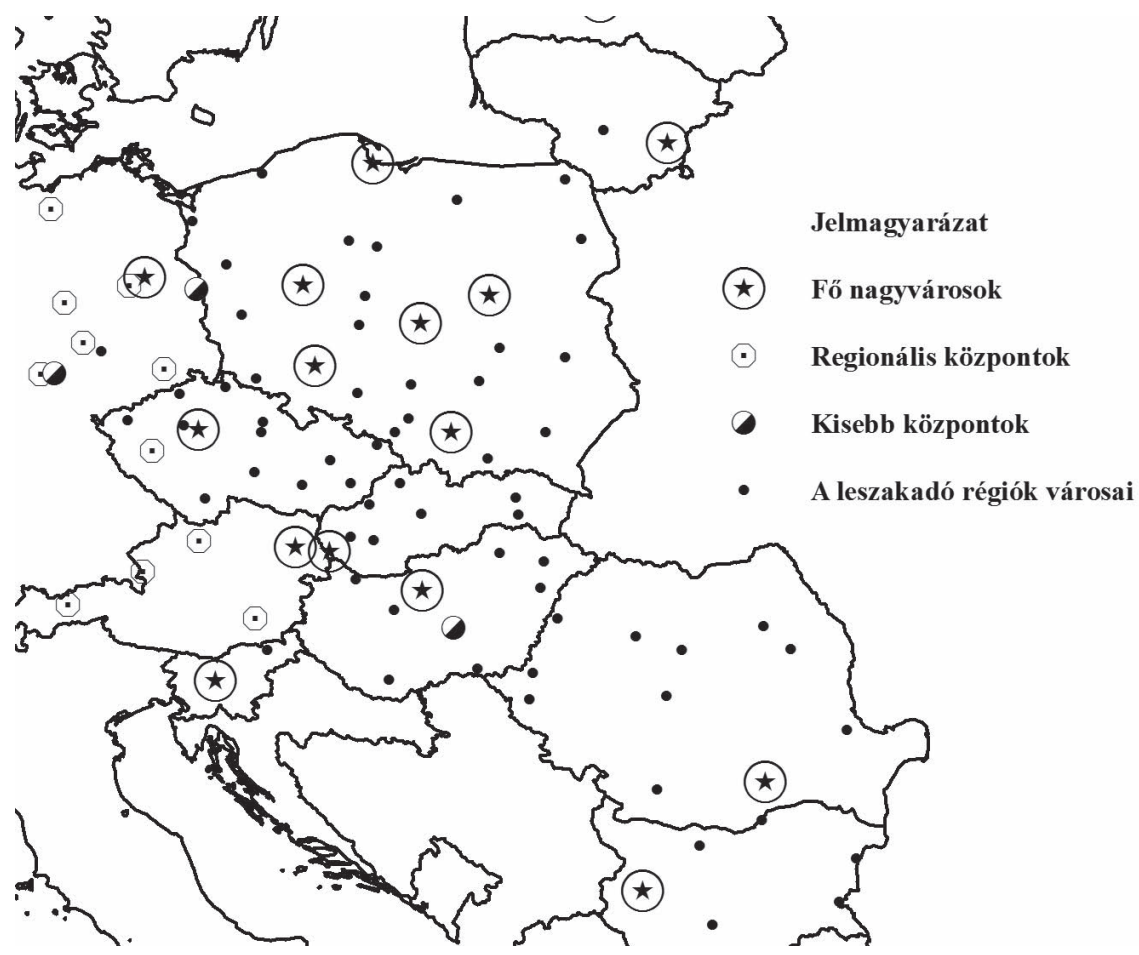

Forrás: RWI, Difu, NEA, PRAC 2010 alapján. 
3. táblázat: Kelet-közép-európai várostípusok 2004-ben

Urban typology of Central and Eastern Europe, 2004

\begin{tabular}{|c|c|}
\hline \multirow[t]{2}{*}{ Fö nagyvárosok } & Vezetö európai fö-és nagyvárosok: Bécs \\
\hline & $\begin{array}{l}\text { Nemzeti fó- és nagyvárosok: Berlin, Pozsony, Bukarest, Budapest, Gdańsk, Krakkó, } \\
\text { Łódź, Ljubljana, Poznań, Prága, Riga, Szófia, Varsó, Wrocław }\end{array}$ \\
\hline \multirow[t]{3}{*}{ Regionális központok } & Regionális szolgáltató központok: - \\
\hline & $\begin{array}{l}\text { Regionális innovációs központok: Erfurt, Graz, Halle an der Saale, Lipcse, } \\
\text { Magdeburg, Plzeň, Schwerin }\end{array}$ \\
\hline & Regionális központok, növekvő népességgel: Drezda, Linz, Potsdam, Salzburg \\
\hline \multirow[t]{2}{*}{ Kisebb központok } & Kisebb közigazgatási központok: Frankfurt, Kecskemét, Weimar \\
\hline & Kisebb központok növekvő népességgel: - \\
\hline \multirow[t]{3}{*}{$\begin{array}{l}\text { A leszakadó régiók } \\
\text { városai }\end{array}$} & $\begin{array}{l}\text { Strukturális adaptáció alatt lévő városok: } 54 \text { kelet-közép-európai város, pl. Győr, } \\
\text { Katowice, Nagyszeben, Kolozsvár, Arad, Hradec Králové }\end{array}$ \\
\hline & Leszakadó városok: Bákó, Brăila, Călărași, Craiova, Gyurgyevó, Nowy Sącz, Piatra \\
\hline & Neamț, Plovdiv, Radom, Rusze, Suwałki, Marosvásárhely, Várna \\
\hline
\end{tabular}

Forrás: RWI, Difu, NEA, PRAC 2010 alapján.

Összességében újra ki kell jelenteni, hogy az urban audit adatbázisára alapozott vizsgálatok fenntartással kezelendők, egyrészt az adatok elérhetősége, megbízhatósága, másrészt pedig a területi aggregáció szintje miatt.

\section{A területi szintű vidékiesség és városiasság főbb összefüggései}

A vidéki és városi térségek lehatárolására jelentős hatású az OECD által kidolgozott, népsűrűségen alapuló módszertan. A metodika két területi szintet vesz figyelembe, a településit és a NUTS 3-at. A 150 fö $/ \mathrm{km}^{2}$ alatti népsürűségü településeket vidékinek tekintjük. A NUTS 3 szinten három kategória van: túlnyomóan vidéki régiók (a vidéki népesség aránya több mint $50 \%$ ), átmeneti régiók (15-50\% közötti vidéki népesség) és városi régiók (a népesség kevesebb mint 15\%-a él vidéki közösségekben). Később a városi dimenzió még hangsúlyosabbá vált az egyes kategóriákban: ha egy túlnyomóan vidéki térségben van egy legalább 200000 fös város és ez a térség népességének 25\%-át jelenti, akkor átmeneti kategóriába kerül az adott régió. Ha egy átmeneti régióban van 500000 főnél népesebb város és ez a népesség több mint $25 \%$-át jelenti, akkor városi régiónak minősül a térség. Az ötödik kohéziós jelentésben (EC 2010b) újabb lehatárolás jelent meg, népességi rácsok segítségével városi és vidéki klasztereket határoltak le. Városi az a klaszter, ahol a népsűrüség legalább 300 fö/ $\mathrm{km}^{2}$ és az egységet minimum 5000 fó alkotja. Az 500 km²-nél kisebb NUTS 3 térségeket a modell összevonja egy vagy több szomszédjával. Ezek után a NUTS 3 térségeket a népességi arány alapján sorolja be: ahol a négyzetek többsége rurális (vagyis az össznépesség 50\%-a, vagy több egység nem éri a városi kritériumot) túlnyo- 
móan vidékiesnek nevezi, ahol az arány 20-50\%, ott átmeneti a kategória, és ahol a népesség kevesebb mint 20\%-a él vidékies rácsban, az túlnyomóan városi régiónak számít (EC 2011). A kategorizálás ezzel nem ér véget, a város (mint a különböző szolgáltatások és munkahelyek tere) szerepe alapján azon átmeneti és túlnyomóan vidéki térségek, amelyek esetében 45 percnyi utazás alatt elérhető egy legalább 50000 fő népességű város, városközelinek tekinthetők, ahol ez a feltétel nem teljesül, az távoli jelzőt kap.

A NUTS 3 szintű vidékiesség és városiasság értelmezéséhez járulnak hozzá Bengs és Schmidt-Thomé (2006) ESPON-eredményei. Elsőként a város-vidék kapcsolatok főbb tényezőit azonosítja a jelentés, majd ezek összefüggéseit faktorelemzés segítségével elemzi. A mutatók között területhasználati, népességi, jóléti, infrastrukturális és mobilitási indikátorokat találunk. A faktorelemzés kettéosztotta a városi és a vidéki tereket: az elsőben a településstruktúra és az áramlás jellemzői sűrűsödnek, a másodikba pedig a mezőgazdasági területek, az erdők és a természetközeli területek arányai kerültek. Ezután második lépésként három, a környezeti és funkcionális tulajdonságokat figyelembe vevő kritériumot határoztak meg, ezek a népsűrüség, a NUTS 3 régió központi városának státusza, valamint a mesterséges, mezőgazdasági és „maradék” (erdő, vizenyős területek és vízfelszín) területek aránya. ${ }^{8} \mathrm{~A}$ városi hatás mértékét a népsürüség és a térségben lévő város státusza fejezi ki. Ha a népsűrűség a vizsgált térség (EU-27-ek, Norvégia és Svájc) átlaga felett van vagy a város a MEGA-kategóriába sorolható, akkor a városi hatás magas. Ha egyik kritérium sem teljesül, akkor alacsony városi hatásról beszélhetünk. Az emberi beavatkozás meghatározása a CORINE-adatbázis területhasználati adatbázisa alapján történt (a jelentés bevallott hiányossága, hogy a területhasználati adatok az 1990-es évre vonatkoznak). Nagymértékü emberi beavatkozásról abban az esetben beszélhetünk, ha a mesterséges területek aránya átlag feletti. Közepes emberi beavatkozás esetében a mezőgazdasági (és ha lehetséges, a „maradék” kategóriájú) területhasználat is átlag feletti. Kismértékü emberi beavatkozásról pedig akkor szólhatunk, ha a „maradék” területek aránya átlag feletti. Hat kategóriát alakítottak ki, ${ }^{9}$ melyek eloszlása némely esetben szélsőséges. Az erős városi hatású régiókban jelentős koncentrációt figyelhetünk meg: a terület $27 \%$-án a népesség közel 70\%-a él, itt koncentrálódik a gazdasági teljesítmény 78\%-a. A gazdasági teljesítmény koncentrációja igen szélsőséges: a 2004 előtt csatlakozott országokban termelik meg annak 95\%-át, a többi az új tagállamoké. Az INTERACT és az ESPON (2007) az egyes kategóriák alapján összegezte a főbb társadalmi-gazdasági sajátosságokat (4. táblázat).

A módosítható területi egység problémájával foglalkozó ESPON 3.4.3 jelentés (ESPON 2006) a tipizálást elkészítette NUTS 2 szintre is. A kutatási anyag kiemeli a városi és vidéki tipizálás eltérő eredményeit a közép-európai térségben, ami az aggregációból fakadó információveszteségből adódik (3. ábra). Bajorország NUTS 3 szinten diverz képet nyújt, NUTS 2 szinten viszont egyértelmüen városi térséggé „válik”. Hasonló jelenség figyelhető meg Lengyelországban is. (Itt érdekesség, hogy Varsó és vonzáskörzete NUTS 3 szinten erős városi hatás- 
4. táblázat: Főbb társadalmi-gazdasági sajátosságok a vidékies és városias térségekben Main social and economic characteristics of the rural and urban areas

\begin{tabular}{|c|c|c|c|c|}
\hline & & \multicolumn{3}{|c|}{ „Vidékiség” } \\
\hline & & Beépitett & Kezelt & Egyéb (vadon) \\
\hline \multirow[t]{12}{*}{ Népsürüség } & Magas & Magas GDP/fö & Legmagasabb & Turisztikai dominancia - \\
\hline & & Alacsony a leszakadó & népességnövekedés & külföldi (főleg európai) \\
\hline & & régiók aránya & Legmagasabb gazdasági & vendégek \\
\hline & & Az elérhetőség magas & növekedés & \\
\hline & & szintü & Nagyarányú a leszakadó & \\
\hline & & & régiók jelenléte & \\
\hline & Alacsony & Népességcsökkenés & Magas gazdasági & Alacsony \\
\hline & & Legalacsonyabb & növekedés & népességnövekedés \\
\hline & & gazdasági növekedés & Alacsony elérhetőség & Gyenge elérhetőség \\
\hline & & Nagyarányú leszakadó & & \\
\hline & & térségek & & \\
\hline & & Alacsony elérhetőség & & \\
\hline
\end{tabular}

A kereszttáblában nem az eredeti kutatás elnevezéseit alkalmazták. A „vidékiség” az emberi beavatkozás mértékét mutatja, a beépített területek a nagyfokú, a kezelt területek a közepes, míg az egyéb (vadon) pedig a gyenge beavatkozás „szinonimái”.

Forrás: INTERACT, ESPON 2007 alapján.

3. ábra: Közép-európai vidéki és városi térségek NUTS 2 és NUTS 3 szinteken értelmezve Rural and urban areas on different NUTS 2 and NUTS 3 scales in Central Europe
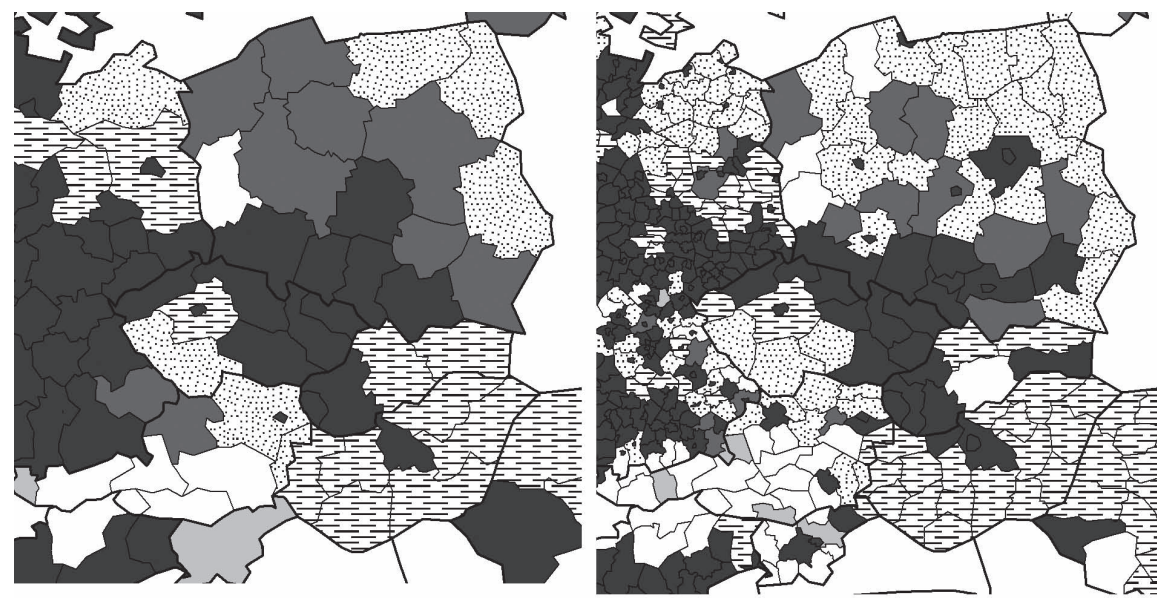

Erös városi hatás, nagyfokú emberi beavatkozás

$\square$ Erős városi hatás, közepes emberi beavatkozás $\square$ Erōs városi hatás, kismértékủ emberi beavatkozás EGyenge városi hatás, nagyfokú emberi beavatkozás Gyenge városi hatás, közepes emberi beavatkozás $\square$ Gyenge városi hatás, kismértékü emberi beavatkozás

Forrás: ESPON 2006 alapján. 
sal és nagyfokú emberi beavatkozással jellemezhető, vajdasági - NUTS 2 - szinten viszont egy kategóriával visszaesik.) Nagyobb visszaesés írható le Kassa és Komárom-Esztergom megyék esetében, viszont Csehországban szinte alig változott a két szinten elvégzett besorolás. A vidékiesség és a városiasság értelmezését és összehasonlítását nagyban befolyásolja a lehatárolás módszertana is. Kelet-Németországban például jóval több várost értelmeznek NUTS 3 régióként, mint Csehországban, Magyarországon, Romániában vagy Bulgáriában. Előbbiben 26 várost (kreisfreie Stadt) találunk, míg utóbbiakban csupán a fővárosok jelennek meg önálló régióként.

A nemzeti szinten eltérő lehatárolásokból adódó problémák részbeni kiküszöbölésére két módszert is kínál az európai szakirodalom: egyrészt a főbb városok szükebb-tágabb vonzáskörzettel együtt történő lehatárolását, másrészt pedig a településmorfológiát is figyelembe vevő vizsgálatokat.

A város mint területi egység képét tovább differenciálja, hogy számos kiadványban (Dijkstra 2009; EC 2010b, 2013) megtaláljuk a nagyvárosi régió kifejezést. Ezek területi lehatárolásának alapja az urban audit LUZ térsége, tehát a város és annak vonzáskörzete. A nagyvárosi régiók lehatárolása az EU és az OECD harmonizált módszertanán alapul. ${ }^{10} \mathrm{~A}$ nagyvárosi térség egy vagy több NUTS 3 térségből áll. Mivel a LUZ és a NUTS 3 területek határai nem esnek egybe, ezért azon NUTS 3 térségek, ahol az adott LUZ népességének legalább 50\%-a él, az az adott LUZ nagyvárosi térsége. ${ }^{11} \mathrm{~A}$ városmag lehatárolására a korábban említett négyzetrácsmódszert alkalmazták, a vonzáskörzetek alapját pedig a népszámlálások alapján felmért ingázási adatok jelentik. ${ }^{12}$ Háromféle nagyvárosi térség létezik: fővárosi térség (mint pl. Budapest és Pest megye, Prága és Közép-Csehország), második szintű nagyvárosi térség (a Kolozsvárt magába foglaló Kolozs megye) és a kisebb nagyvárosi térség (például Brassó megye). Csak a nagyvárosi térségnek van népességszám-megkötése, az azon belüli kategóriák meghatározása a nemzeti sajátosságokhoz kötődik. A nagyvárosi régió szintjén történő vizsgálatok általában a GDP, a népesség és a munkaerö-piaci helyzet sajátosságainak kimutatására törekszik. Hasonló metodikával határozta meg az ESPON a másodlagos növekedési pólusokat (EIUA, UT, MRI, IFU, UC 2012) is, viszont több nagyvárosi térséget azonosítottak. A kutatás hipotézise szerint a területi teljesítmény főbb mozgatórugói az alábbi tényezők: innováció, humán tőke, elérhetőség, életminőség és kormányzati kapacitás. Az egyes mutatók közötti kapcsolatokat nem elemzi a jelentés, az egyes dimenziók operacionalizálása után csupán összehasonlító elemzéseket végeztek a kutatók.

Szintén városokat tipizál az ESPON FOCI projekt (EUROREG 2010). A vizsgálat megfigyelési egységei a nagyvárosi térségek és regionális hinterlandjuk. ${ }^{13}$ A térségi lehatárolás kivételes: Budapest esetében a regionális hinterland BácsKiskun, Fejér, Komárom-Esztergom, Nógrád, Heves és Jász-Nagykun-Szolnok megyékből áll, Prága esetében pedig Csehország nyugati fele (gyakorlatilag a történelmi Bohémia) alkotja a hinterlandot. A kelet-közép-európai térben 22 nagyvárosi térség és regionális háttérország létezik. A mindkét térségre külön- 
külön elvégzett faktor- és klaszterelemzés eredménye egy város- és várostérségi kategorizálás. A kelet-közép-európai térség 2004-ben és 2007-ben csatlakozott fövárosainak mindegyike tradicionális vidéki térségekkel körülvett nemzeti növekedési pólusnak számít, a lengyel nagyobb városok és Várna periferikus területek kisebb városai. Berlin és tágabb környezete munkaerő-piaci problémákkal küszködő háttérországgal körülvett monocentrikus szolgáltatási központ, Graz és Linz a hegyvidéki térségben lévő kis szolgáltatási központ kategóriájába tartozik. Lipcse és Drezda problémás területen elhelyezkedő, szerkezetátalakítás alatti városnak számít. Véleményem szerint a vizsgálatban kérdéses, hogy a tágabb hinterland ténylegesen funkcionális összetartozást is jelent-e. Budapest esetében például Jász-Nagykun-Szolnok megyéből inkább csak a Jászság tekinthető háttérországnak, míg a megye többi része nem (OFTK 2014).

A nemzeti lehatárolások sajátos korrekciójaként értelmezhető a többközpontúságot célként kitűző, a településmorfológiát is figyelembe vevő régióvizsgálat. Az egyik ESPON-projekt (BBR, IRS 2006) az európai térség NUTS 2 és NUTS 3 régióinak többközpontúságát vizsgálta klaszterelemzés segítségével. ${ }^{14}$ Az elemzésbe öt mutatót vontak be: településsűrűség, a kisvárosi népesség aránya, a funkcionális városi térségek és a MEGA-térségek jelenléte (dummy változók), valamint a legnagyobb város népességi aránya az adott régióban. A klaszterelemzés eredményeként hét régiótípus született (5. táblázat).

5. táblázat: Kelet-közép-európai régiótipizálás a településmorfológia alapján

Typology of Central and Eastern European regions by settlement morphology

\begin{tabular}{|c|c|c|}
\hline Közös nevezök & Föbb jellemzök & Példák \\
\hline \multirow[t]{9}{*}{ MEGA területek dominanciája } & Magas településsűrűség, nincs & Prága, Berlin, Bécs \\
\hline & kisváros, központi település & \\
\hline & népessége $100 \%$ körüli & \\
\hline & A központi település népessége & Közép-Magyarország, Pozsony, \\
\hline & magas, alacsony kisvárosi & Délnyugat (Bulgária) \\
\hline & népesség & \\
\hline & Alacsonyabb a központi & Nyugat (Románia), Mazóvia \\
\hline & település népessége, alacsony & \\
\hline & kisvárosi népesség & \\
\hline \multirow[t]{8}{*}{ MEGA-térség hiánya } & FUA-dominancia & Kujávia-Pomeránia, „Közép- \\
\hline & & Ausztria" \\
\hline & Alacsonyabb FUA-népesség & $\begin{array}{l}\text { Brandenburg, Észak-Alföld, } \\
\text { Közép-Szlovákia }\end{array}$ \\
\hline & A kisvárosi népesség alacsony, a & Közép-Csehország, Közép- \\
\hline & településsűrűség csekély & Morvaország \\
\hline & A központi település népessége & Burgenland, Türingia, Dél- \\
\hline & alacsony, csekély & Dunántúl \\
\hline & településsűrüség & \\
\hline
\end{tabular}

Forrás: ESPON 2006 alapján. 
Összességében többletinformációt kapunk a különböző szintű régiók policentrikus térszerkezetéről, de mégis kritikával szükséges illetni a vizsgálatot. A régiók többségében ugyanis látszólagos regionalizációval (Tóth 2003) szembesülhetünk: a fejlesztési régióknak nincs sok közük a valóságos térszerveződéshez, inkább csak a politikai pragmatizmus (a fejlesztési források lehívása, a fejlesztési stratégiák életbeléptetése és monitoringja) szülte azokat. „Kiváló” példa erre a MEGA-területek dominanciájával jellemezhető klaszterek harmadik csoportját képviselő Mazóvia: Varsó régiója a „tudatosan vezérelt” aggregációs információveszteség miatt lett konvergenciarégió 2004-2006 között és az azt követő pénzügyi ciklusban is. ${ }^{15}$

Módszertani (és különösen adatkezelési) szempontból talán az egyik legérdekesebb, legsokszínűbb vizsgálat az ESPON (2012) keretén belül született. A közép-európai fóvárosokat (Bécs, Prága, Pozsony, Budapest, Ljubljana) górcső alá vevő, a metropolizálódást és a policentrikus fejlődést vizsgáló POLYCE kutatásban egy-egy város teljesítményének értékelésére számos területi szintet alkalmaztak. Megjelenik az urban audit-ból a CC (magváros) és a LUZ (agglomeráció), a NUTS 3 és a NUTS 2 szint, egyes indikátorok esetében pedig a FUA- és MEGA-szintek is előkerülnek. Az összehasonlító elemzés (a főbb faktorok: gazdasági teljesítmény, népességi mutatók, mobilitás, környezet és életminőség) eredménye szerint a közép-európai fővárosok rangsora a következőképpen alakul: Bécs, Prága, Pozsony, Ljubljana és Budapest.

\section{Összegzés}

Tanulmányom a napjainkban is átalakuló kelet-közép-európai régió területi sajátosságainak kimutatását tüzte ki célul, mégpedig a városok, a városias terek értelmezésével, kitekintve a kelet-közép-európai térségre. Kutatási kérdéseim a városok és a városi térségek meghatározását, a különböző területi szinteken való értelmezést, a mérést, a módszertant, a városi teljesítmény kimutatását célozták.

Összességében kijelenthető, hogy a város nem minden esetben város, annak szúkebb-tágabb vonzáskörzete vagy hinterlandja szinte minden esetben megjelenik a különböző társadalmi-gazdasági tartalmú területi elemzésekben. A föbb európai empíriák áttanulmányozása alapján megállapítható, hogy legalább annyira diverz a város- és a várostérség-tipizálás, mint a vidéki terek esetében.

Ugyanakkor a vizsgálatok többségét fenntartásokkal kell kezelnünk. A városi szintű kutatások (konkrétan az urban audit) esetében számos faktor nehezíti az egységes értelmezést, ilyenek például az adatbázis elérhetősége, megbízhatósága, és a területi aggregáció sem tekinthető megbízhatónak. A városok kisugárzó, fejlődést generáló szerepe miatt fontosnak tartom az egységes módszertanon alapuló vonzáskörzet-lehatárolást. 
A területi vizsgálatok értelmezésének egyik kulcskérdése a lehatárolás metodikája, annak sajátosságai és következményei. A gyakran előforduló módosítható területi egység problémájára megoldás a vonzáskörzettel való együttes kezelés vagy a településmorfológia sajátosságainak figyelembevétele. Természetesen egyik megoldás sem tökéletes, utóbbinál például a látszólagos regionalizáció következményei nehezítik az értelmezést. Ezért a vizsgált térség ismerete elengedhetetlen a pontos és tényszerü vizsgálatok elvégzéséhez.

A kelet-közép-európai régió várostérképének megrajzolása a fentiek alapján nem egyszerű feladat. A városok és városias térségek számos tipizálásával találkozhatunk, és az egységesítést nehezíti, hogy az egész térségre vonatkozó elemzés kevésnek mondható. Természetesen Bécs, Berlin, az új tagállamok fövárosai és a nagyobb városok elsőbbsége, teljesítménye megkérdőjelezhetetlen a régióban, a kis és közepes népességű városok komplex feltárása még várat magára. Jelen pillanatban ez a korábban említett okok miatt kivitelezhetetlen, ezért a NUTS 3 szintű városi térségvizsgálatok tűnnek megfelelőnek, természetesen a településmorfológiai sajátosságokkal kiegészítve. Egyrészt e térségi szint áll a legközelebb a városi szinthez, másrészt pedig a városi fejlődés, teljesítmény indikátorkészlete ezen a szinten tűnik kielégítőnek.

\section{Jegyzetek}

1 Kunzmann (1992) Kék szőlő térszerkezeti modellje is hasonló elképzelésen alapul. A főbb európai városok mint szőlőszemek jelennek meg (szűkebb-tágabb vonzáskörzetükkel), ezek együttesen egy fürtöt alkotnak. Gorzelak (1997) szintén városi alapon határolta le híres térszerkezeti modelljét, a Közép-európai banánt.

2 Beszédes összefüggéseket ismertet az ötödik kohéziós jelentés (EC 2010b): a nyugat-európai urbanizáltabb térségben magasabb az anyagilag nélkülöző és az anyagilag súlyosan nélkülöző népesség aránya, mint a kevésbé városiasodott térségekben.

3 Két megvilágításban is beszélhetünk policentrikusságról. Az első a morfológiához kapcsolódik, ami azt jelenti, hogy adott területen hogyan oszlanak el a városi körzetek; a második a városi körzetek közötti kapcsolatra (pl. az együttműködések hálózatára) vonatkozik. (Illés 2005)

4 Alapegységnek a funkcionális városi területet (functional urban area - FUA) tekinti az ESPON, amely egy városi központ (morphological urban area - MUA) és az azzal szoros gazdasági kapcsolatban álló környezet (labour pool) együttese (Radvánszki 2007).

5 Minden dimenziót két mutató képvisel, a versenyképességi indexek kivételével egyszerü számtani átlagot használtak az összegzésnél. Az egy főre jutó GDP-t kétharmados, a vállalatok jelenlétét egyharmados aránnyal vették figyelembe.

6 Itt a lehatárolás kiegyenlítéséről, egységesítéséről van szó, a fővárosok összehasonlíthatóságának érdekében. A kategória a város körüli beépített területeket is tartalmazza.

7 Az alkalmazott versenyképességi modell a versenyképességi fa (Lukovics 2008). Ennek alapjai a tehetség, az innováció, a kapcsolódás és a vállalkozókészség.

8 A népsűrüség és a MEGA-területek között pozitív korrelációs kapcsolat van, mint ahogy a mesterséges területek aránya és a népsürüség között is. (Ez utóbbi esetében igen szoros a kapcsolat.)

9 A kategóriák a következők: erős városi hatás, nagyfokú emberi beavatkozás; erős városi hatás, közepes emberi beavatkozás; erős városi hatás, kismértékű emberi beavatkozás; gyenge váro- 
si hatás, nagyfokú emberi beavatkozás; gyenge városi hatás, közepes városi hatás; gyenge városi hatás, kismértékủ emberi beavatkozás.

10 A kettő közötti különbség az, hogy az OECD csak a nagyobb nagyvárosokat veszi számba és csakis az OECD-tagországokban, míg az EU szerint népességi kritérium van: legalább 250000 főnek kell lennie egy nagyvárosi térségben.

11 Hasonló módszertani sajátossággal találkozhatunk az ESPON FOCI projektben is, ott viszont szigorúbb megkötés él: az 50\% helyett 70\%-nak kell élnie az adott NUTS 3 térségben, térségekben.

12 Hasonló módszertant alkalmaz Annoni és Dijkstra (2013) a hatodik kohéziós jelentést megalapozó, az EU regionális versenyképességét vizsgáló írásában (amely például Berlint és Brandenburgot, Bécset és Alsó-Ausztriát egyként kezeli).

13 Ezt együttesen makrorégiónak nevezi a jelentés. A Belügyminisztérium és a VÁTI által szerkesztett (2011), az ESPON kutatási eredményeit magyarul bemutató kiadvány város és vonzáskörzetnek nevezi ezt a területi szintet. Véleményem szerint a város és regionális hinterlandja vagy háttérországa kifejezést indokolt alkalmazni.

14 Azon országok esetében, ahol egyetlen NUTS 2 térséget találunk (balti államok, Szlovénia), ott a világosabb értelmezhetőség miatt alkalmazták a NUTS 3 szintet.

15 Varsó NUTS 3 térség (Miasto Warszawa) már a 2000-2002-es időszakban is hasonló teljesítménnyel bírt, mint az akkori térségi éllovas Prága, mára viszont megelőzte azt. Mazóvia hat NUTS 3 térségből áll, a fejlett Varsóból és öt fejletlen alrégióból. Többségük ma az egy főre jutó, vásárlóerő-paritáson mért GDP alapján az EU-átlag 50\%-án áll.

\section{Irodalom}

Annoni P., Dijkstra L. (2013): EU regional competitiveness index. RCI 2013. http://ec.europa.eu/regional_policy/sources/docgener/studies/pdf/6th_report/rci_2013_report_final.pdf (Letöltés: 2013. szeptember 22.)

BBR [Bundesamt für Bauwesen und Raumordnung], IBR [Institute for Regional Development and Structural Planning] (2006): International analyses of transnational and national territories based on ESPON results. ESPON 2.4.2 final report. http://www.espon.eu/export/sites/default/Documents/ Projects/ESPON2006Projects/PolicyImpactProjects/ZoomIn/fr-2.4.2-full-r.pdf (Letöltés: 2009. december 1.)

Belügyminisztérium, VÁTI (2011): Helyünk és jövőnk Európában. ESPON eredmények magyar szemmel. Budapest

Bengs C., Schmidt-Thomé K. (2006): Urban-rural relations in Europe. ESPON 1.1.2. Final report. http://www.espon.eu/export/sites/default/Documents/Projects/ESPON2006Projects/Thematic Projects/UrbanRural/fr-1.1.2_revised-full_31-03-05.pdf (Letöltés: 2009. december 01.)

Bretagnolle, A., Delisle, F., Mathian, H., Lizzi, L., Guérois, M., Averlant, G. (2011): LUZ specifications (2004). ESPON technical report. http://www.espon.eu/export/sites/default/Documents/Toolsand Maps/ESPON2013Database/3.6_TR-Urban_Audit.pdf (Letöltés: 2013. január 23.)

Dijkstra, L. (2009): Metropolitan regions in the EU. Regional Focus, 1. http://ec.europa.eu/regional_policy/ sources/docgener/focus/2009_01_metropolitan.pdf (Letöltés: 2012. december 22.)

EC (1999): ESDP. European Spatial Development Perspective. Towards balanced and sustainable development of the territory of the European Union. Office for Official Publications of the European Communities, Luxembourg

EC (2007): State of European cities report - Adding value to the European urban audit. http://ec.europa.eu/ regional_policy/sources/docgener/studies/pdf/urban/stateofcities_2007.pdf(Letöltés: 2012. május 11.)

EC (2010a): Survey on perception of quality of life in 75 European cities. http://ec.europa.eu/regional_policy/sources/docgener/studies/pdf/urban/survey2009_en.pdf (Letöltés: 2012. május 10.)

EC (2010b): Befektetés Európa jövőjébe. Ötödik jelentés a gazdasági, társadalmi és területi kohézióról. Az Európai Unió Kiadóhivatala, Luxembourg 
EC (2011): Regional focus. Regional typologies: a compilation. http://ec.europa.eu/regional_policy/sources/docgener/focus/2011_01_typologies.pdf (Letöltés: 2012. május 10.)

EC (2013): Nyolcadik eredményjelentés a gazdasági, társadalmi és területi kohézióról. A válság regionális és városi dimenziója. http://www.europarl.europa.eu/meetdocs/2009_2014/documents/regi/pr/ 1009/1009773/1009773hu.pdf (Letöltés: 2012. szeptember 22.)

EIUA [European Institute for Urban Affairs], UT [University of Tampere], MRI [Metropolitan Research Institute], IFU [Institut Francais d'Urbanisme], UC [University College] (2012): SGPTD second tier cities and territorial development in Europe: Performance, policies and prospects. Final report. http://www.espon.eu/export/sites/default/Documents/Projects/AppliedResearch/SGPTD/SGPTD_Final_Report_-_Final_Version_27.09.12.pdf (Letöltés: 2013. december 22.)

EUROREG [Centre for European Regional and Local Studies] (2010): Metropolitan macroregions in Europe: from economic landscapes to metropolitan networks (Cities and their hinterlands). FOCI Future Orientations for Cities final scientific report. ESPON Coordinate Unit, Luxembourg

ESPON (2005): Potentials for polycentric development in Europe. ESPON 1.1.1. Project report. http://www.espon.eu/export/sites/default/Documents/Projects/ESPON2006Projects/Thematic Projects/Polycentricity/fr-1.1.1_revised-full.pdf (Letöltés: 2007. április 12.)

ESPON (2006): The modifiable areas unit problem. ESPON 3.4.3 final report. http://www.espon.eu/export/sites/default/Documents/Projects/ESPON2006Projects/StudiesScientificSupportProjects/MAUP/espon343_maup_final_version2_nov_2006.pdf (Letöltés: 2009. január 12.)

ESPON (2007): Study on urban functions. ESPON 1.4.3. Project report. http://www.espon.eu/export/sites/default/Documents/Projects/ESPON2006Projects/StudiesScientificSupportProjects/UrbanFunctions/fr-1.4.3_April2007-final.pdf (Letöltés: 2014. április 10.)

ESPON (2012): POLYCE. Metropolisation and polycentric development in Central Europe. Final report. http://www.espon.eu/export/sites/default/Documents/Projects/TargetedAnalyses/POLYCE/FR/ POLYCE_FINAL_MAINREPORT.pdf (Letöltés: 2013. szeptember 15.)

Gorzelak, G. (1997): Regional development and planning in East Central Europe.. In: Keune, M. (ed.): Regional development and employment policy: Lessons from Central and Eastern Europe. ILO, Budapest, 62-76.

Illés D. (2005): Az ESPON program első befejezett programja. Falu-Város-Régió, 3., 106-109.

INTERACT, ESPON (2007): Polycentric urban development and rural-urban partnership - thematic study of INTERREG and ESPON activities. http://www.espon.eu/export/sites/default/Documents/Projects/ESPON2006Projects/ESPONINTERactStudies/PolycentricUrbanDevelopment/fr-INTERACTPoly-Jan2007.pdf (Letöltés: 2010. március 12.)

Kezán A. (2006): Urban audit: az egységes városstatisztikai adatbázis. Konferencia-előadás a Magyar Regionális Tudományi Társaság IV. Vándorgyülésén. Szegeden. www.mrtt.hu/vandorgyulesek/2006/eloadasok/kezan.ppt (Letöltés: 2012. május 12.)

Kunzmann, K. R. (1992): Zur Entwicklung der Stadtsysteme in Europa. Mitteilungen der Österreichischen Geographischen Gesellschaft, 134., 25-50.

Lukovics M. (2008): Térségek versenyképességének mérése. JatePress, Szeged

NFGM (Nemzeti Fejlesztési és Gazdasági Minisztérium), VÁTI (2010): Kézikönyv az Európai Unió Területi agendájának hazai érvényesitéséhez. Greenlight, Budapest

OFTK (2014): Országos Fejlesztési és Területfejlesztési Koncepció. Nemzetgazdasági Tervezési Hivatal, Budapest

Radvánszki Á. (2007): Egy koncepció - sok megközelítés? Falu-Város-Régió, 4., 15-24.

Rechnitzer J. (2006): Az Európai Unió regionális és városfejlesztési politikájának újabb jellemzői. In: Lengyel I., Rechnitzer J. (szerk.): Kihívások és válaszok: A magyar épitőipari vállalkozások lehetőségei az EU-csatlakozás utáni időszakban. NOVADAT Kiadó, Győr, 105-124.

RWI [Rheinisch-Westfälisches Institut für Wirtschaftsforschung], Difu [German Institute of Urban Affairs], NEA [Transport research and training], PRAC [Policy Research \& Consultancy] (2010): Second state of European cities report. Research project for the European Commission, DG Regional Policy. http://ec.europa.eu/regional_policy/sources/docgener/studies/pdf/urban/stateofcities_ 2010.pdf (Letöltés: 2013. február 22.)

Tóth Sz. (2003): A régiók Európája. Korunk, 14., 172-179. 